\title{
Kepemimpinan Kepala Desa Dalam Rangka Tata Kelola Pemerintahan Di Kabupaten Bandung Dan Kabupaten Bandung Barat
}

\author{
Agus Subagyo, Agustina Setiawan, Titin Rohayatin, Iing Nurdin, \\ Bayu Septiansyah, Harky Ristala \\ Fakultas Ilmu Sosial dan Ilmu Politik, Universitas Jenderal Achmad Yani \\ Penulis korespondensi : agus.subagyo@lecture.unjani.ac.id
}

\begin{abstract}
Abstrak: Artikel ini menguraikan tentang kepemimpinan Kepala Desa dalam rangka tata kelola Pemerintahan di Kabupaten Bandung Barat dan untuk mendeskripsikan kepemimpinan kepala desa dalam membangun desa. Deskripsi tersebut diperoleh melalui pengamatan, wawancara, dan penelaahan dokumen. Hasil kegiatan pengabdian kepada masyarakat ini menyimpulkan bahwa Kepala Desa sebagai pemimpin formal di desa sebagai seorang motivator, fasilitator dan mediator sangat penting dalam menentukan keberhasilan setiap program dan rancangan pembangunan yang telah direncanakan. Oleh karena itu fungsi ini harus dilaksanakan dan implementasikan oleh seorang kepala desa dalam rangka pengembangan dan pembangunan desa. Selain itu kepala desa juga yang merupakan administrator pemerintah, administrator masyarakat dan administrator pembangunan mempunyai peranan yang sangat penting dalam menumbuhkan, menggerakkan dan meningkatkan partisipasi masyarakat untuk ikut aktif dalam kegiatan pembangunan desa.
\end{abstract}

Kata kunci: Kepemimpinan, Desa, Tata Kelola Pemerintahan.

\begin{abstract}
The article describes the leadership of the Village Head in the framework of governance in West Bandung Regency and describes the leadership of the village head in developing the village. It was obtained via observation, interviews and document review. The community empowerment concluded that the Village Head as the formal leader in the village as a motivator, facilitator and mediator is very important in determining the success of each program and development plan that has been planned. Therefore, this function must be carried out and implemented by a village head in the context of village development and development. In addition, the village head is also a government administrator, community administrator and development administrator who has a very important role in growing, mobilizing and increasing community participation to actively participate in village development activities.
\end{abstract}

Keywords: Leadership, Village, Governance.

\section{Pendahuluan}

Desa merupakan persekutuan masyarakat adat yang mengikat diri menjadi satu komunitas masyarakat dan diakui oleh negara sebagai kesatuan masyarakat formal (Yansen, 2014). Desa memiliki peran yang strategis dalam mensejahterakan masyarakatnya. Berdasarkan statistik

Volume 2, Nomor 1, Maret 2021 | 65

Kepemimpinan Kepala Desa Dalam Rangka Tata Kelola Pemerintahan Di Kabupaten Bandung Dan Kabupaten Bandung Barat

Agus Subagyo, Agustina Setiawan, Titin Rohayatin, Iing Nurdin, Bayu Septiansyah, Harky Ristala https://doi.org/10.26874/jakw.v2i1.105 
menunjukkan bahwa masyarakat Indonesia $65 \%$ bermukim di desa. Dengan kondisi demikian dapat dikatakan bahwa mayoritas orang Indonesia adalah orang desa (Yansen, 2014). Untuk mewujudkan kelestarian lingkungan pada suatu wilayah, gerakan-gerakan kecil dapat dimunculkan dari desa. Kekayaan alam dan sumber daya sebagian besar berada di desa, namun pengelolaan yang tidak tepat oleh pemimpin desa dalam hal ini adalah kepala desa akan berdampak pada kesejahteraan masyarakat. Kepala desa sebagai kepanjangan dari pemerintah memegang kekuasaan penting di desa, meskipun dibatasi oleh undang-undang.

Suatu kehormatan dan perhargaan tertinggi saat terpilih sebagai pimpinan, apalagi jika berhasil menjadi kepala desa. Ini jabatan terhormat yang akan selalu diberikan penghormatan oleh warga di seluruh desa, namun sekarang hal tersebut tidak cukup. Setiap kepala desa harus bisa berlaku adil, jujur, transparan dan sesuai dengan aturan pemerintah. Hal ini sesuai dengan Undang-Undang No. 6 Tahun 2014 tentang Desa. Selain itu ada juga Peraturan Pemerintah (PP) No. 43 Tahun 2014, yang mengatur tentang desa dan bagaimana aplikasi dari UU No. 6 Tahun 2014 tersebut. Ada juga beberapa instruksi khusus dari Permenkeu, Permendagri.dan Permen (Peraturan Menteri) Desa \& PDT.

Dalam Undang-Undang No. 23 Tahun 2014, Desa adalah satu kesatuan masyarakat hukum yang memiliki batas-batas wilayah yurisdiksi, berwenang untuk mengatur dan mengurus kepentingan masyarakat setempat, berdasarkan asal-usul dan adat istiadat setempat, yang diakui atau dibentuk dalam sistem pemerintahan Nasional yang berada di kabupaten / kota, sebagaimana disebutkan dalam UUD Negara Republik Indonesia Tahun 1945. Landasan pemikiran dalam pengaturan mengenai desa, adalah keanekaragaman, partisipasi, otonomi asli, demokratisasi dan pemberdayaan masyarakat.

Kepemimpinan dipandang sangat penting karena adanya kenyataan bahwa penggantian pemimpin seringkali mengubah kinerja suatu unit, instansi atau organisasi, adanya faktor internal yang mempengaruhi keberhasilan organisasi adalah kepemimpinan, mencakup proses kepemimpinan pada setiap jenjang organisasi, kompetensi dan tindakan pemimpin yang bersangkutan (Batts \& Leary, 2010; Yukl, 1989).

Bertitik tolak pada pengertian kepemimpinan seperti disebut diatas, maka seorang pemimpin itu dituntut agar dapat memenuhi suatu persyaratan dalam melaksanakan suatu kegiatan organisasi, baik organisasi pemerintah maupun swasta. Lebih dari pada itu, seorang pemimpin itu juga dituntut untuk memiliki pengetahuan yang lebih baik dibandingkan dengan 
bawahannya, berdedikasi baik, serta pengalaman yang luas. Untuk dapat memenuhi persyaratan tersebut, maka dipandang penting seorang pemimpin itu untuk senantiasa meningkatkan pengetahuan, keterampilan, dan kepribadiannya melalui pembinaan watak (character building), (Solekhan, 2014). Jadi kinerja kepemimpinan merupakan inti dari manajemen yang merupakan motor penggerak sumber daya dan fungsi manajemen serta alat lainnya.

Membuat desa menjadi sejahtera, makmur dan tenteram dapat membantu pemerintah untuk memecahkan masalah di perkotaan, karena tidak akan ada warga desa yang datang ke kota secara besar-besaran untuk mencari pekerjaan. Pasalnya sudah ada pekerjaan yang sesuai kemampuan warga desa, ini menjadikan desa lebih maju dan putra terbaik desa tidak perlu mengadu nasib ke kota. Pengaturan ini membawa kepala desa sebagai pimpinan, namun bagaimana jadinya jika sebagai pimpinan tidak tahu bagaimana caranya memimpin. Ini akan memancing terjadinya kekacauan, bahkan setelah menjabat. Ada banyak kecurangan yang bisa terjadi tanpa diketahui warga, dimana desa bukan lagi tempat yang nyaman.

Dewasa kini, paradigma 'Desa Membangun' telah menempatkan karakter pemerintahan Desa sebagai campuran antara masyarakat berpemerintahan (self governing community) dengan pemerintahan lokal (local self government). Sifat campuran tersebut berdampak pada perubahan posisi kepala desa/kepala desa adat sebagai salah satu bentuk pemimpin formal di desa. Dengan kewenangan untuk mengatur dan mengurus desa dibutuhkan para pemimpin yang dapat mempengaruhi moral dan kepuasan kerja, kualitas kehidupan kerja dan tingkat prestasi pemerintahan desa. Para pemimpin desa memainkan peranan kritis dalam membantu kelompok, kelembagaan dan organisasi desa atau masyarakat untuk mencapai tujuan visi, misi desa yang telah ditetapkan.

Secara umum, tipe kepemimpinan kepala Desa dapat dibagi menjadi tiga yaitu kepemimpinan regresif yaitu kepemimpinan yang berwatak otokrasi, kepemimpinan konservatif involutif yaitu model kepemimpinan yang ditandai oleh hadirnya kepala desa yang bekerja apa adanya, menikmati kekuasaan dan kekayaan, serta tidak berupaya melakukan inovasi yang mengarah pada demokratisasi dan kesejahteraan, dan kepemimpinan inovatif progresif yaitu kepemimpinan yang ditandai oleh adanya kesadaran baru mengelola kekuasaan untuk kepentingan masyarakat banyak. Aspek paling fundamental dalam menjalankan kepemimpinan Desa adalah Legitimasi, hal ini terkait erat dengan keabsahan, kepercayaan dan 
hak berkuasa. legitimasi berkaitan dengan sikap masyarakat terhadap kewenangan. Kewenangan untuk memimpin, memerintah, serta menjadi wakil atau representasi dari masyarakatnya.

Desa memiliki sejumlah kewenangan yang merujuk pada Pasal 19 huruf a dan b UU Desa. Kewenangan tersebut, antara lain kewenangan berdasarkan hak asal usul dan kewenangan lokal berskala Desa. Kewenangan hak asal usul merupakan kewenangan yang diberikan karena Desa merupakan entitas yang sudah ada sebelum NKRI lahir pada tahun 1945 dan sudah memiliki susunan asli. Sementara kewenangan lokal berskala Desa merupakan kewenangan untuk mengatur dan mengurus kepentingan masyarakat Desa yang telah dijalankan oleh Desa atau mampu dan efektif dijalankan oleh Desa atau yang muncul karena perkembangan Desa dan prakarsa masyarakat Desa.

Berdasarkan latar belakang tersebut, kegiatan pengabdian kepada masyarakat dilakukan untuk mengetahui kepemimpinan Kepala Desa dalam rangka tata kelola Pemerintahan di Kabupaten Bandung Barat. Adapun yang menjadi rumusan masalahnya adalah bagaimana kepemimpinan Kepala Desa dalam rangka tata kelola Pemerintahan di Kabupaten Bandung Barat. Adapun tujuan penelitian ini ialah untuk mengetahui dan mendeskripsikan kepemimpinan Kepala Desa dalam rangka tata kelola Pemerintahan di Kabupaten Bandung Barat.

\section{Metode}

Kegiatan ini menggunakan pendekatan deskriptif, proses penelitian kualitatif bersifat seni, dan disebut sebagai metode interpretive karena data hasil penelitian berkenaan dengan interpretasi terhadap data yang ditemukan di lapangan (Sugiyono, 2013). Lebih lanjut (Sugiyono, 2013) menjelaskan bahwa metode penelitian kualitatif digunakan pada kondisi objek yang alamiah dimana peneliti sebagai instrumen kunci. Oleh karena itu kegiatan ini lebih menekankan pada metode atau pendekatan deskriptif kualitatif. Kegiatan yang dilakukan ini bertempat di desa wilayah Kabupaten Bandung Barat. Waktu kegiatan adalah rentang waktu yang digunakan selama proses penyusunan proposal hingga kegiatan berlangsung, mulai dari tahap persiapan sampai pada tahap penyusunan laporan sesuai dengan sasaran kegiatan.

Pengumpulan data dalam kegiatan ini menggunakan prosedur pengumpulan data melalui observasi, wawancara, dan dokumentasi. Melalui observasi, pelaksana dapat meyakini, dapat 
melihat dan dapat mengamati sendiri yang kemudian dilanjutkan dengan pencatatan perilaku serta kejadian sebagaimana adanya. Wawancara dilakukan secara langsung kepada semua pihak yang berkompeten dalam kegiatan ini, agar informasi yang didapatkan tidak meragukan dan dapat dipertanggung jawabkan. Dokumentasi berupa pengumpulan data dari sumbersumber non visual yakni berupa dokumen-dokumen atau arsip-arsip dan rekaman yang ada relevansinya dengan kebutuhan data yang dibutuhkan dalam kegiatan.

\section{Hasil dan Diskusi}

\subsection{Kepemimpinan Kepala Desa}

Kepemimpinan Desa merupakan kewenangan untuk mengatur dan mengurus kepentingan masyarakat Desa yang telah dijalankan oleh Desa atau mampu dan efektif dijalankan oleh Desa atau yang muncul karena perkembangan Desa dan prakarsa masyarakat Desa. Selain itu, dalam UU Desa juga merinci kewenangan lokal berskala Desa yang antara lain meliputi; bidang pemerintahan Desa, pembangunan Desa, kemasyarakatan Desa dan pemberdayaan masyarakat Desa berdasarkan prakarsa masyarakat, hak asal usul, dan adat istiadat Desa. Fungsi kepemimpinan dan gaya kepemimpinan diperlihatkan dalam Gambar 1.

Menurut tipe kepemimpinan regresif, kepemimpinan adalah dirinya sendiri, tidak ada orang lain dan apa yang diucapkan olehnya dianggap keputusan Desa dan harus dipatuhi, bahasa lainnya sabdo pandito ratu. Selain itu, kepemimpinan ini tipe ini selalu menolak untuk transparan, tidak ada mekanisme pertanggungjawaban kepada publik. Sementara itu, kepemimpinan konservatif-involutif memaknai pemerintahan cenderung Normatif serta prosedural. Selanjutnya dalam menjalankan pemerintahan sesuai prosedur yang ada, dalam hal akuntabilitas tipe kepemimpinan ini hanya untuk membuat dokumen laporan pertanggung jawaban, dalam hal transparansi penyelenggaraan pemerintahan biasanya hanya mengikuti tata tertib yang sudah ada. Sedangkan untuk tipe kepemimpinan inovatif-progresif memaknai pemerintahan desa sebagai sebuah proses menjalankan pemerintahan yang melibatkan partisipasi/prakarsa masyarakat, transparan serta mengedepankan akuntabilitas kinerja.

Kegiatan pembangunan desa terdiri dari perencanaan, pelaksanaan, dan pengawasan kegiatan. Dalam kepemimpinan regresif pembangunan desa harus sesuai dengan kemauannya, program pembangunan diarahkan untuk kesejahteraan dirinya sendiri. Sedangkan kepemimpinan konservatif involutif akan melaksanakan pembangunan desa sesuai mekanisme 
perencanaan pembangunan yang sudah ada dan yang penting baginya terdapat dokumen perencanaan program pembangunan. Semantara itu kepemimpinan inovatif-progresif, pembangunan desa dilaksanakan dengan cara melibatkan partisipasi masyarakat mulai dari merencanakan, melaksanakan serta mengawasi proyek pembangunan.

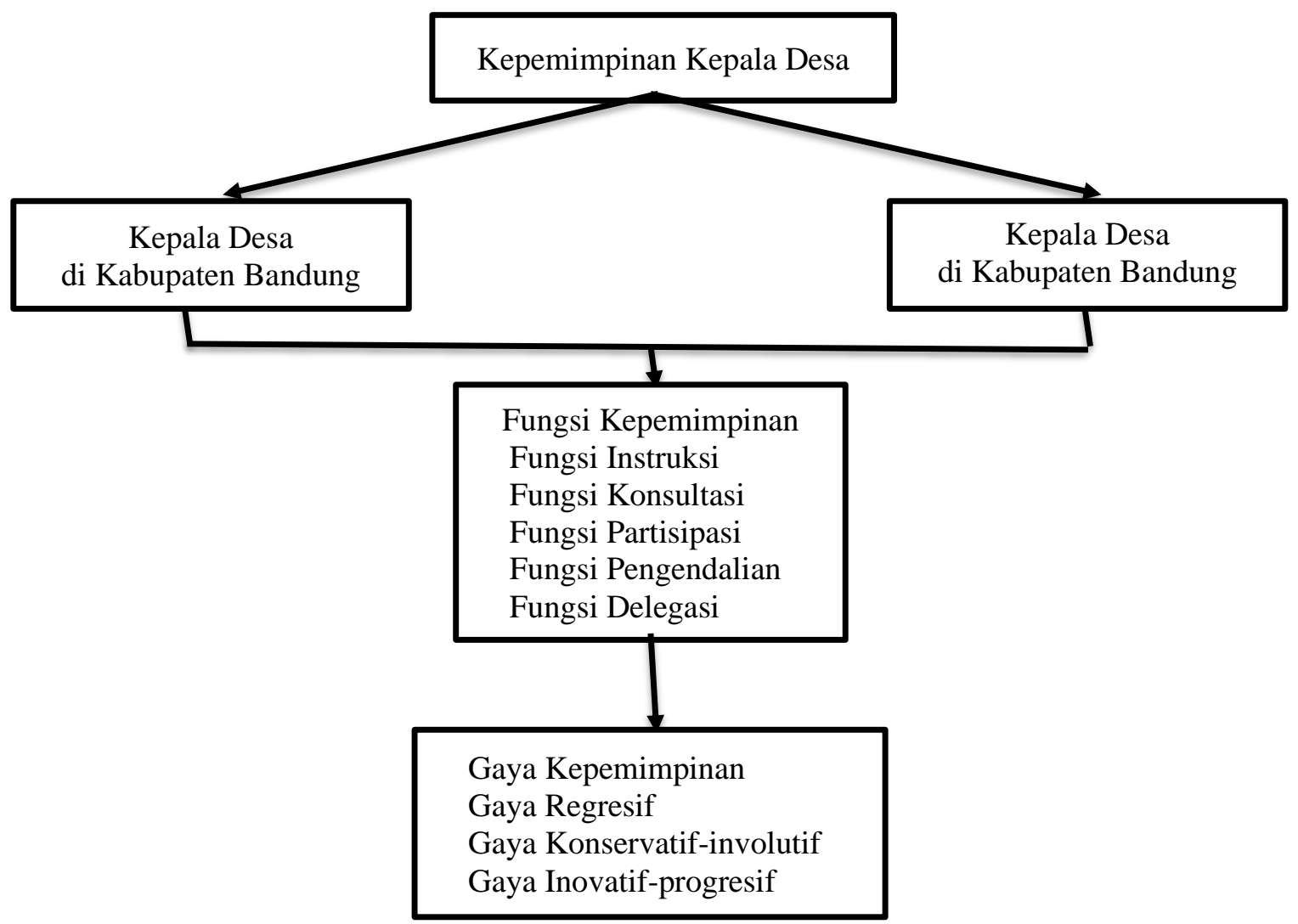

Gambar 1. Fungsi Kepemimpinan dan Gaya Kepemimpinan

Kepemimpinan Kepala Desa dalam hal ini adalah pelaksanaan tanggung jawab Desa dalam memelihara ketentraman dan ketertiban. Dalam kepemimpinan regresif, untuk menjaga ketentraman dan ketertiban Desa ditangani oleh dirinya sendiri, pemimpin ini akan mengontrol kehidupan masyarakat Desa, bila terdapat masyarakat yang dianggap meresahkan dirinya sendiri akan ditindak, serta diintimidasi. Sedangkan dalam tipe kepemimpinan konservatifinvolutif dalam hal menjaga ketentraman dan ketertiban di Desa secara prosedural akan dilaksanakan dengan cara adanya koordinasi dengan kepolisian maupun Babinsa. selanjutnya dalam tipe kepemimpinan inovatif-progresif Kepala Desa akan melibatkan seluruh unsur masyarakat termasuk untuk bersama-sama menjaga ketentraman dan ketertiban Desa.

Dalam Kepemimpinan Kepala Desa terkait pemberdayaan masyarakat desa dilakukan 
dengan jalan mendampingi masyarakat agar berdaya. Dalam kepemimpinan regresif biasanya menolak untuk mendampingi masyarakat desa, masyarakat yang berdaya dianggap sebagai ancaman bagi posisinya. Sedangkan dalam kepemimpinan konservatif-involutif hanya akan memberdayakan keluarga, kerabat atau warga masyarakat yang dapat dikendalikan olehnya. Selanjutnya dalam tipe kepemimpinan inovatif-progresif akan melakukan pemberdayaan Desa dengan memunculkan prakarsa masyarakat, selain itu tipe kepemimpinan ini akan melakukan kaderisasi dan menyiapkan kader-kader desa serta membuka akses untuk peningkatan kapasitas SDM masyarakat desa.

Kondisi saat ini melihat tingginya minat serta ketertarikan masyarakat untuk menjadi Kepala Desa di wilayah Kabupaten Bandung Barat maupun di Kabupaten Bandung sehingga menimbulkan suhu politik di desa sangat tinggi. Semua masyarakat Desa yang memenuhi persyaratan mempunyai hak untuk dipilih dan untuk memilih dalam proses Pemilihan Kepala Desa. Bahkan jauh dari sebelumnya bahwa Kepala Desa sudah dipilih langsung oleh masyarakat sebelum diselenggarakannya Pemilihan Kepala Daerah secara langsung. Pemilihan Kepala Desa secara langsung saat ini mempunyai daya magnet tinggi terhadap peminatan masyarakat di desanya. Masyarakat berlomba dan memperebutkan suara masyarakat untuk mendapatkan jabatan Kepala Desa, dengan masing-masing Bakal Calon Kepala Desa memiliki tim sukses masing-masing. Ketertarikan untuk menjadi Kepala Desa saat ini bukan hanya melanda kepada Kepala Desa Petahana melainkan ke setiap golongan masyarakat, misalnya saja ketertarikan untuk menjadi Kepala Desa melanda kepada TNI, POLRI, ASN, Pengusaha, masyarakat lainnya dan tidak mengenal usia, bahkan setiap individu masyarakat rela menanggalkan profesi sebelumnya untuk mengikuti bursa Pemilihan Kepala Desa.

Dengan tingginya minat masyarakat untuk menjadi Kepala Desa, Peraturan Perundangundangan Nomor 6 Tahun 2014 tentang Desa membatasi calon Kepala Desa hanya bisa maksimal 5 orang. Jika pada kenyataannya Bakal Calon Kepala Desa memiliki lebih dari 5 orang maka harus dilakukan tes potensi akademik untuk menjaring melalui perangkingan menjadi 5 orang. FISIP Unjani sering sekali bekerjasama dengan Panitia Pemilihan Kepala Desa dari Kabupaten Bandung Barat dipercaya dan ditunjuk sebagai penyelenggara tes potensi akademik bagi Desa yang memiliki bakal calon lebih dari 5 orang. Bahkan dengan adanya Pemilihan Kepala Desa Serentak pun Unjani pernah menjadi bagian yang mensukseskan terselenggaranya Pemilihan Kepala Desa Serentak baru-baru ini yaitu dalam tahapan pemilihan 
kepala desa yaitu berperan sebagai penyelenggara Tes Potensi Akademik bagi Desa yang memiliki Bakal Calon lebih dari 5 orang. Saat ini sebagai realisasi dan implementasi dari bentuk kerjasama dengan Kabupaten Bandung Barat, maka FISIP Unjani mengadakan Pendidikan dan Pelatihan Kepemimpinan bagi para Kepala Desa se Kabupaten Bandung dan Bandung Barat. Dengan Pelatihan ini diharapkan dapat meningkatkan kemampuan dari para Kepala Desa dalam proses penyelenggaraan pemerintahan desa pada masa kepemimpinannya.

\subsection{Kepemimpinan Dalam Mengelola Kewenangan TUPOKSI}

Kepemimpinan Kepala Desa dapat mempengaruhi terhadap Desa apabila Kepala Desa tersebut dapat bekerja dengan baik sesuai dengan tugas dan fungsinya serta dapat memberikan motivasi kerja yang baik dengan bawahannya. Desa sebagai organisasi pemerintah terendah yang merupakan tumpuan segenap pelaksana urusan pemerintahan dan pembangunan, dengan berbagai potensi sumber daya yang dimiliki desa.

Dalam upaya menjalankan kewenangan Kepemimpinan Kepala Desa sesuai dengan tupoksinya, berikut tabel sasaran serta strategi Kepala Desa di Kabupaten Bandung dan Kabupaten Bandung Barat untuk mewujudkan pembangunan desa. Wilayah, sasaran, dan strategi dari kegiatan diberikan dalam Tabel 1.

Tabel 1. Wilayah, sasaran, dan strategi

\begin{tabular}{|c|c|c|}
\hline Wilayah & Sasaran & Strategi \\
\hline $\begin{array}{l}\text { Kabupaten } \\
\text { Bandung }\end{array}$ & $\begin{array}{l}\text { 1. Meningkatnya Partisipasi } \\
\text { Masyarakat dalam Pembangunan } \\
\text { Wilayah } \\
\text { 2. Meningkatnya Kapasitas dan } \\
\text { Kapabilitas Internal }\end{array}$ & $\begin{array}{l}\text { 1. Peningkatan keberdayaan } \\
\text { masyarakat pedesaan } \\
\text { 2. Peningkatan partisipatif } \\
\text { masyarakat dalam membangun } \\
\text { desa } \\
\text { 3. Peningkatan kapasitas aparatur } \\
\text { pemerintah desa } \\
\text { 4. Pengembangan lembaga } \\
\text { ekonomi pedesaan }\end{array}$ \\
\hline $\begin{array}{l}\text { Kabupaten } \\
\text { Bandung } \\
\text { Barat }\end{array}$ & $\begin{array}{l}\text { 1. Meningkatnya kapasitas } \\
\text { pemberdayaan masyarakat } \\
\text { perdesaan } \\
\text { 2. Meningkatnya tata kelola, } \\
\text { manajemen, administrasi, dan } \\
\text { organisasi pemerintahan desa }\end{array}$ & $\begin{array}{l}\text { 1. } \begin{array}{l}\text { Peningkatan Keberdayaan } \\
\text { Masyarakat Desa }\end{array} \\
\text { 2. Pengembangan } \\
\text { Ekonomi Perdesaan } \\
\text { 3. Peningkatan } \\
\text { Masyarakat Dalam Membangun } \\
\text { Desa }\end{array}$ \\
\hline
\end{tabular}


Dari hasil kegiatan ini menunjukan bahwa Kepala Desa sudah melaksanakan perannya sesuai kewenangan serta tupoksinya baik di Kabupaten Bandung maupun di Kabupaten Bandung Barat sebagai fasilitator dalam pelaksanaan pembangunan di Desa serta dari hasil penelitian yang diperoleh dalam penelitian ini peneliti menemukan bahwa dalam memfasilitasi pelaksanaan pembangunan telah dilakukan dengan baik, yaitu secara fisik maupun non fisik. Kepala desa sebagai mediator melakukan pembinaan kepada masyarakatnya secara kekeluargaan. Perannya sebagai motivator dalam pelaksanaan pembangunan dengan bertindak bijaksana sebagai kepala desa yang menjadi figur dalam pelaksanaan pembangunan yang ada adalah hal yang paling penting dalam desa karena kepala desa merupakan pimpinan yang bertanggung jawab di desa.

\subsection{Kepemimpinan Dalam Menyusun Peraturan}

Peraturan Desa merupakan peraturan yang dibuat oleh Kepala Desa bersama-sama dengan Badan Permusyawaratan Desa (dalam Undang-Undang No 6 tentang Desa) untuk mengatur urusan Rumah Tangga di Desa. Ruang lingkup berlakunya peraturan desa hanya pada desa dimana peraturan desa itu dibuat.

Adapun penyusunan Peraturan Desa yang diprakarsai Oleh Kepala Desa, sebagai berikut:

1. Rancangan Perdes yang telah disusun,wajib dikonsultasikan kepada masyarakat desa.

2. Rancangan Perdes dapat dikonsultasikan pada Camat untuk dapat masukan.

3. Konsultasi diutamakan kepada masyarakat atau kelompok masyarakat yang terkait langsung dengan substansi materi pengaturan.

4. Masukan dari masyarakat desa dan camat digunakan pemerintah desa untuk tindak lanjut proses penyusunan rancangan peraturan desa

5. Rancangan Perdes yang telah dikonsultasikan disampaikan Kepala Desa kepada BPD untuk dibahas dan disepakati bersama.

Dalam Undang-Undang No 6 tentang Desa serta Peraturan Menteri Dalam Negeri Republik Indonesia Nomor 111 tahun 2014 tentang Pedoman Teknis Peraturan di Desa dan Peraturan yang berkaitan dengan hal ini maka Kepala Desa mempunyai peranan penting dalam pembangunan dan perkembangan dan kemajuan Desa.

Hal tersebut sesuai dengan hasil wawancara dengan Kepala Desa Padalarang Kabupaten Bandung Barat Bapak Karom : 
"Dalam menjalankan Pemerintahan Desa yang sangat sulit ialah membentuk suatu tatanan masyarakat yang berdasarkan hukum. Kepala desa mempunyai tugas berat dalam membentuk suatu tatanan masyarakat yang sadar akan hukum salah satunya partisipasi dalam melibatkan diri membuat suatu produk hukum dalam desa yang dipimpinnya, dalam membuat Rancangan Peraturan Desa, Kepala Desa selalu mengutamakan kepentingan yang masyarakat desa biar dirasakan oleh masyarakat desa lainnya seperti, setiap tahunnya kepala desa dan perangkat desa membuat peraturan desa yakni peraturan mengenai Anggaran Belanja Desa, ini merupakan sifatnya diharuskan setiap akhir tahunnya untuk mengetahui dan sebagai dasar untuk melakukan pembelanjaan keuangan desa untuk tahun berikutnya”.

Berdasarkan hal tersebut diatas, Kepala Desa mempunyai kewenangan untuk mengajukan Rancangan Peraturan Desa, dalam mengajukan peraturan desa biasanya Kepala Desa mempertimbangkan partisipasi masyarakat desa. Dalam menggunakan kewenangan Kepala Desa bermitra dengan Lembaga Pemberdayaan Masyarakat Desa (LPMD) lembaga inilah yang menampung aspirasi masyarakat, sebelum sampai ke Kepala Desa. Lembaga Pemberdayaan Masyarakat Desa ini mengadakan atau menjalankan tugasnya dengan cara mengadakan Musyawarah Rencana Pembangunan Desa (Musdes) di tingkat RT, dari hasil Musyawarah Perencanaan Pembangunan Desa tingkatan RT dan selanjutnya dibawa ke Musyawarah Rencana Pembangunan Desa tingkat Dusun dan hasil Musrembangdes tingkat dusun ini baru mengadakan musyawarah Rencana Pembangunan Desa tingkat desa.

Didalam musyawarah tingkat desa inilah untuk membahas keluhan, saran, masukan dan hal-hal ain yang berhasil dihimpunan dari masyarkat melalui Musdes tingkat RT dan Musdes tingkat Dusun untuk merencanakan dan merumuskan suatu Peraturan Desa. Rancangan Peraturan Desa disusun bersama Kepala Desa dengan LPMD dan mitra Desa lainnya, sebelum sampai Musyawarah dengan Badan Permusyawaratan Desa (BPD). Sehingga dalam praktik dilapangan bahwa kepala desa sudah menjalankan amanat dari undang-undang, hal ini dibuktikan dengan menjadi agenda setiap tahun dari kepala desa adalah membuat peraturan desa mengenai Anggaran Pendapatan Belanja Desa (APBDes). Hal ini menuntut Kepala Desa untuk bisa bekerjasama untuk menampung aspirasi masyarakat desa mulai dari tingkat bawah. Sehingga peranan Kepala Desa dalam mengajukan Peraturan Desa sangatlah penting serta didukung SDM perangkat desa yang berkualitas, agar supaya aspirasi masyarakat dapat diserap dan bisa membangun desa kearah yang lebih mandiri serta Otonomi sesuai yang diharapkan oleh Negara Kesatuan Republik Indonesia.

Volume 2, Nomor 1, Maret 2021| 74

Kepemimpinan Kepala Desa Dalam Rangka Tata Kelola Pemerintahan Di Kabupaten Bandung Dan Kabupaten Bandung Barat 


\subsection{Kepemimpinan Dalam Meningkatkan Pendapatan Desa}

Dengan adanya Undang-Undang No 6 tentang Desa tentunya membawa angin segar kepada desa, karena dalam aturan tersebut secara terperinci sangat jelas diatur mengenai kewenangan-kewenangan desa, termasuk dalam pengelolaan keuangan, dengan ditetapkannya pembagian dana kepada setiap desa dari dana APBN, oleh karena itu memungkinkan desa meningkatkan kreatifitasnya dalam meningkatkan pendapatan desa. Kewenangan lainnya yang memberikan keleluasaan Kepada Desa adalah dalam hal pembentukan Badan Usaha Milik Desa, seperti yang diatur dalam Peraturan Menteri Desa Nomor 4 Tahun 2015 Tentang pendirian, pengurusan dan pengelolaan, dan pembubaran badan usaha milik desa.

BUMDes merupakan pilar kegiatan ekonomi yang berfungsi sebagai lembaga sosial dan lembaga komersial yang berpihak kepada kepentingan masyarakat dan bertujuan untuk mencari keuntungan melalui potensi sumber daya lokal. Adapun tujuan dari pendirian BUMDes sendiri secara lengkap termuat dalam Permendagri Nomor 4 Tahun 2015 sebagai dasar untuk melaksanakan ketentuan Pasal 142 Peraturan Pemerintah Nomor 43 Tahun 2014 tentang Peraturan Pelaksanaan Undang-Undang Nomor 6 Tahun 2014, sebagai berikut:

1. Meningkatkan Perekonomian Desa

2. Mengoptimalkan Aset Desa

3. Meningkat Usaha Masyarakat

4. Kerja sama Antar Desa dan/atau Pihak Ketiga

5. Menciptakan Peluang dan Jaringan Pasar

6. Membuka Lapangan Kerja

7. Meningkatkan Kesejahteraan Masyarakat

8. Meningkatkan Pendapatan Masyarakat dan PAD

Hal tersebut sesuai dengan hasil wawancara dengan Kepala Desa Cintakarya Kabupaten Bandung Barat Bapak Agus Hambali

"Salah satu faktor pendukung meningkatkan pendapatan asli desa yaitu sumbersumber pendapatan yang sebenarnya banyak seperti pengelolaan potensi desa seperti pertanian, sehingga saya memfokuskan untuk bagaimana meningkatkan peluang peningkatan pendapatan desa dari sektor pertanian, seperti dengan melakukan pemberdayaan kepada petani, dan bantuan bibit serta pupuk untuk meningkatkan hasil kualitas pertanian di desa kami, disamping itu pun di desa kami untuk meningkatkan dari adanya BUMDes sebagai potensi peningkatan pendapatan dengan memaksimalkan BUMDes" 
Adapun hasil wawancara dengan Kepala Desa Margaasih Kabupaten Bandung Bapak Iyep Jamaludin

"peraturan desa sebenarnya dibuat dengan tujuan untuk mencapai Lembaga Perekonomian desa yang mandiri dalam meningkatkan kesejahteraan masyarakat desa dan meningkatkan pendapatan asli desa. Dapat memberikan pelayanan terhadap kebutuhan masyarakat dan meningkatkan kesempatan berusaha dalam mengurangi pengangguran di desa. Dan Melindungi kepentingan masyarakat melalui upaya-upaya yang mengenal pada terciptanya pemberdayaan dan pengembangan potensi perekonomian masyarakat desa secara keseluruhan”.

Berdasarkan hal tersebut diatas, peran Kepala Desa sebagaimana dalam pendekatan teori fungsi manajemen, dapat dijelaskan sebagai berikut: Pertama, dalam proses perencanaan pemerintah desa harus melakukan perencanaan dalam pelaksanaan program dan keuangan desa, yang dapat dibuktikan dengan pelaksanaan musdes. Kedua, harus adanya pengorganisasian badan usaha milik desa sesuai dengan ketentuan peraturan yang ada yaitu dalam Peraturan Menteri Desa Nomor 4 Tahun 2015, dimana dalam pasal 4 ayat 1 disebutkan bahwa desa dapat mendirikan BUM Desa berdasarkan Peraturan Desa tentang Pendirian BUM Desa. Ketiga, dalam hal pelaksanaan, penatausahaan, pelaporan, dan pertanggung jawaban oleh pemerintah desa. Keempat, peran Kepala Desa dalam pengawasan pengelolaan keuangan desa, agar penghasilan (keuntungan) yang diperoleh dari usaha-usaha desa, teridentifikasi dengan jelas, dan dapat diketahui oleh seluruh masyarakat desa.

\section{Kesimpulan}

Kepemimpinan Kepala Desa sangat menentukan terhadap masa depan pada Pemerintah Desanya. Kinerja Kepala Desa mempunyai pengaruh besar terhadap kemajuan dan kualitas dari Pemerintah Desa dalam rangka meningkatkan kesejahteraan masyarakat di desanya. Seluruh rangkaian kegiatan ditutup dengan acara seminar melalui pendidikan dan pelatihan kepemimpinan pemerintahan bagi para kepala desa se Kabupaten Bandung dan se Kabupaten Bandung Barat Barat ini yang meliputi: Pendidikan dan pelatihan "Kepemimpinan dalam musyawarah desa, Kepemimpinan dalam gerakan usaha ekonomi desa, Kepemimpinan dan pendamping desa, Membangun legitimasi masyarakat. Membangun keteladanan pemimpin, Ketaatan pada hukum", diharapkan dapat meningkatkan kapasitas Pemerintahan Desa dalam rangka proses penyelenggaraan pemerintahan desa. Mengingat Pemerintah Desa merupakan pintu utama untuk kemajuan nasional. Pembangunan desa merupakan bagian integral dari 
pembangunan nasional. Pemerintah Desa merupakan Garda terdepan untuk memajukan pembangunan nasional. Terlaksananya pembangunan nasional diawali dengan pembangunan desa sang berkualitas. Kualitas pembangunan desa didukung oleh kinerja dari Pemerintah Desa, kinerja pemerintah desa salah satu indikatornya adalah kepemimpinan yang dimiliki oleh Kepala Desa..

Adapun rekomendasinya sebagai berikut :

1. Para Kepala Desa dapat mewujudkan kepemimpinan inovatif progresif yang ideal untuk menerjemahkan cita-cita UU desa menjadi desa yang kuat, maju, mandiri dan demokratis.

2. Diharapkan para Kepala Desa dapat mewujudkan kepemimpinan yang menyadari pentingnya legitimasi dalam memimpin desanya yang dapat mengoptimalkan kinerja desa dalam mewujudkan kesejahteraan masyarakat, mengangkat harkat dan martabat desa.

3. Kepala desa yang mampu memimpin dan menjalankan kewajibannya yang diamanatkan oleh konstitusi serta taat dan patuh pada hukum yang berlaku di Negara Kesatuan Republik Indonesia.

\section{Daftar Referensi}

Batts, A. \& Leary, M. 2010. Self-Compassion, Stress, and Coping. Social and Personality Psychology Compass, 10, 109 - 116.

Peraturan Menteri Dalam Negeri Republik Indonesia Nomor 111 tahun 2014 tentang Pedoman Teknis Peraturan di Desa.

Siagian, S. P. 2005. Administrasi pembangunan. Jakarta : Bumi aksara.

Solekhan, M. 2014. Penyelenggaraan Pemerintahan Desa. Malang : Setara Press.

Sugiyono. 2013. Metode Penelitian Kuantitatif, Kualitatif, dan R\&D. Bandung: CV. Alfabeta. Undang-Undang No. 6 Tahun 2014 tentang Desa.

Yansen, T.P. 2014. Revolusi Dari Desa, PT Elex Media Komputindo, Jakarta.

Yukl, G. 1989. Leadership in organizations 2nd edition. Englewood Cliffs, NJ: PrenticeHall. 